\title{
Antimalarial Activity and Phytochemical Profile of Ethanolic and Aqueous Extracts of Bidara Laut (Strychnos ligustrina Blum) Wood $^{1}$
}

\author{
Harisyah MANURUNG ${ }^{2} \cdot$ Rita Kartika SARID ${ }^{2, \dagger} \cdot$ Wasrin SYAFII $^{2}$ • \\ Umi CAHYANINGSIH ${ }^{3} \cdot$ Wiwied EKASARI ${ }^{4}$
}

\begin{abstract}
This study aimed to determine the antimalarial effect of the Strychnos ligustrina (SLW) wood extracts and to analyze its phytochemicals. The SLW powder samples were macerated with 100\% ethanol (E100), 75\% ethanol (E75), 50\% ethanol (E50), 25\% ethanol (E25), and aqueous (A100). The extracts were analyzed by LCMS/MS, and its in-vitro antimalarial activity was tested with Plasmodium falciparum. The results showed that the extract yields of E100, E75, E50, E25, and A100 were 4.3, 5.2, 5.3, 4.7, and 3.6\%, respectively. The antimalarial activities of the A100, E25, E50, and E75 extracts were classified as active with $\mathrm{IC}_{50}$ values of 38.6, 42.6, 42.9, and $43.7 \mu \mathrm{g} / \mathrm{mL}$, respectively. But, the antimalarial activity of the E100 extract was classified as slightly active with $\mathrm{IC}_{50}$ values of $87.4 \mu \mathrm{g} / \mathrm{mL}$. The dominant compounds contained in the extracts of A100, E25, E50, E75, and E100 was the alkaloid compound, namely brucine with relative concentrations of 24.96, 24.55, 21.33, 11.79, and 11.62\%, respectively.
\end{abstract}

Keywords: antimalarial activities, aqueous, bidara laut (Strychnos ligustrina Blum), ethanol, phytochemical profile, Plasmodium falciparum

\section{INTRODUCTION}

Indonesia is known as the second mega-biodiversity country in the world because of its immense biodiversity. The natural resources of plants in Indonesia include 30.000 plant species from a total of 40.000 plant species in the world and 940 of them are medicinal plants (Dephut, 2010). One of the plants that can be developed as a medicinal plant is $S$. ligustrina. Empirically, S. ligustrina is used by the Indonesian people, especially from West Nusa Tenggara (NTB) as an antimalarial drug (Setiawan et al., 2014). Several studies showed that $S$. ligustrina wood has a potential active ingredient for antimalarial drugs (Huda, 2006, Syafii et al., 2016a, and Syafii et al., 2016b).

Malaria is one of the infectious diseases which is

${ }^{1}$ Date Received January 21, 2019, Date Accepted August 10, 2019

2 Department of Forest Products, Faculty of Forestry, IPB University (Bogor Agricultural University), Bogor, 16680, Indonesia

${ }^{3}$ Department of Animal Health and Veterinary Medicine, Faculty of Veterinary, IPB University (Bogor Agricultural University), Bogor, 16680, Indonesia

${ }^{4}$ Department of Pharmacognosy and Phytochemical, Faculty of Pharmacy, Airlangga University, Surabaya, 60115, Indonesia

$\dagger$ Corresponding author: Rita Kartika SARI (e-mail: rita_kbu@yahoo.com, ORCID: 0000-0001-5377-1384) 
Harisyah MANURUNG • Rita Kartika SARI • Wasrin SYAFII • Umi CAHYANINGSIH • Wiwied EKASARI

still a health problem in Indonesia. About 4.9 million of the total 262 million people in Indonesia (2\%) live in high endemic areas. About $82 \%$ of malaria cases in Indonesia found in Papua, West Papua, East Nusa Tenggara (NTT), Maluku, and North Maluku with Annual Parasite Incidence (API) per 1000 inhabitants was 31.93, 31.29, 7.04, 5.81, and 2.77, respectively (Kemenkes, 2017). One effort that can be done in controlling malaria is the distribution of antimalarial drugs. However, commercial antimalarial drugs were derived from synthetic ingredients that have side effects and resistant to chloroquine. The chloroquine substitutes such as mefkloin, halofantrin, and artesunate also appear to have adverse side effects such as mild headaches, itching, lethargy, blurred vision, gastrointestinal disorders, and anorexia that limited the application (Mustofa, 2009). To prevent side effects and resistance, malaria treatment in Indonesia uses a combination of antimalarial drugs, Artemisinin-based-Combination Therapy (ACT) (Depkes, 2012). One of the antimalarial compounds that can be used as an artemisinin combination is plant extractive substances. The combination increases the effectiveness of natural extracts/ active compounds and slows down the occurrence of parasitic resistance (Syafii et al., 2016a).

S. ligustrina wood extract is potential to develop as antimalaria drugs. Huda (2006) reported that aqueous extract of $S$. ligustrina wood had an antimalarial activity base on in vivo test with mice and suspected that the responsible compounds were flavonoids and alkaloids. Syafii et al., (2016a) reported that the ethanol extracts derived from multilevel extracts of n-hexane and acetyl acetate of $S$. ligustrina wood had a very active antimalarial inhibition for Plasmodium falciparum growth. Syafii et al., (2016b) reported the fractions 3 and 4 were classified as very active. The GCMS analysis showed that fractions 3 and 4 of the vaccine were dominated by alkaloid compounds, namely strychnine and brucine. The results of antimalarial active compounds identification in S. ligustrina wood can be used as a standard for standardized antimalarial drug products.

The ethanol extract from previous research using multilevel extraction with n-hexane and acetyl acetate was not recommended. To be categorized as a standardized herbal medicine in Indonesia, the plant extract is only allowed to extract using ethanol and aqueous (BPOM, 2004). Therefore, research on the antimalarial activity of S. ligustrina wood extract using ethanol and aqueous and a mixture of both at various concentrations is crucial to produce a safe and active standardized extract. This study aimed to determine the yield extract from S. ligustrina wood extract using $100 \%$ ethanol (E100), 75\% ethanol (E75), 50\% ethanol (E50), 25\% ethanol (E25), and aqueous (A100); determine the in vitro antimalarial activity based on the inhibition of $P$. falciparum; and analyze phytochemical extracts qualitatively and quantitatively with Liquid Chromatography-tandem Mass Spectroscopy (LCMS/MS).

\section{MATERIALS and METHODS}

\subsection{Preparation of Raw Materials}

The S. ligustrina woods with a diameter of 7-10 cm were collected from NTB, Indonesia. The solvents used for extraction were ethanol and aqueous. Other materials were the Rosewell Park Memorial Institute (RPMI) 1640 containing L-glutamine, gentamicin sulfate injection acid, $0.9 \% \mathrm{NaCl}$ and 3.5\%; N-2-hydroxyl ethyl piperazine-N-2-ethane sulfonic acid (HEPES); gentamicin sulfate; serum and red blood cells (RBC); and citric phosphate dextrose anticoagulant (CPD). The tools used were extractor jars, rotavators, ovens, incubators, Millipore membranes, centrifuge tubes, UV lamps, Laminar Air Flow chambers, desiccators, vortex devices, and light microscopes. 
Antimalarial Activity and Phytochemical Profile of Ethanolic and Aqueous Extracts of Bidara Laut (Strychnos ligustrina Blum) Wood

\subsection{Extraction}

$200 \mathrm{~g}$ of S. ligustrina wood powder sized 40-60 mesh was extracted by maceration method using 100\% ethanol, 75\% ethanol, 50\% ethanol, 25\% ethanol, and $100 \%$ aqueous. Extraction was repeated 5 times until a clear filtrate was obtained. The filtrate was concentrated with a rotavator to produce $100 \mathrm{~mL}$ extract solution. About $10 \mathrm{~mL}$ of extract was weighed and put in the oven at $103 \pm 2{ }^{\circ} \mathrm{C}(24 \mathrm{~h})$ for determination of the concentration. The extract weight was obtained by multiply the extract concentration with the extract volume (100 mL). The yield was calculated based on the weight ratio of the extract with powder weight. The yield of each extract was compared using Duncan's test for further analysis. The remaining extract solution (90 mL) was dried in a vacuum oven. The dry extract was used for in vitro antimalarial activity test and phytochemical analysis.

\subsection{In vitro antimalarial activity test}

In vitro antimalarial activity testing referred to Trager and Jensen (1976). The stages were incomplete medium preparation, serum preparation, complete medium preparation, erythrocytes preparation, P. falciparum parasites breeding, maintenance of $P$. falciparum parasites, synchronization, in vitro antimalarial activity in various concentrations $(0.01,0.1,1,10$, and 100 $\mu \mathrm{g} / \mathrm{mL}$ ), harvesting, and data analysis. Data analysis included the calculation of the percentage barriers to the growth of $P$. falciparum under a microscope using the formula:

$\%$ Inhibition $=100 \%-[(\mathrm{Nt} / \mathrm{Nc}) \times 100 \%]$

Information:

$\mathrm{Nt}=$ number of live schizons per 200 asexual $P$. falciparum in testing wells
Nc $=$ number of live schizons per 200 asexual $P$. falciparum in control wells

Antimalarial activity of each extracts was indicated by the value of $50 \%$ Inhibitor Concentration $\left(\mathrm{IC}_{50}\right)$ in units of $\mu \mathrm{g} / \mathrm{mL}$ (Kusch et al., 2011). The $\mathrm{IC}_{50}$ value was determined using a regression equation with a logarithm percent inhibition. The smaller of the $\mathrm{IC}_{50}$ value indicate the higher level of antimalarial activity. The results were classified based on Chinchilla et al., (2011), namely very active $\mathrm{IC}_{50}<5 \mu \mathrm{g} / \mathrm{mL}$, active $\mathrm{IC}_{50}$ 5-50 $\mu \mathrm{g} / \mathrm{mL}$, low $\mathrm{IC}_{50} 50-100 \mu \mathrm{g} / \mathrm{mL}$, and $\mathrm{IC}_{50}$ inactivity> $100 \mu \mathrm{g} / \mathrm{mL}$.

\subsection{Phytochemical qualitative analysis and quantitative analysis with LCMS/MS}

Phytochemical analysis was carried out qualitatively and quantitatively. The qualitative phytochemical analysis referred to Harbone (1996). The detected group compounds were alkaloids, flavonoids, saponins, tannins, triterpenoids, and steroids.

\subsubsection{Alkaloids}

Approximately $3 \mathrm{ml}$ of extracts were added to $3 \mathrm{ml}$ of $1 \% \mathrm{HCl}$ and heated for $20 \mathrm{~min}$. The mixtures were then cooled and used to perform the following tests:

Dragendoff's test: To crude extracts, $1 \mathrm{ml}$ of Dragendoff's reagent was added drop by drop. The formation of a reddish-brown precipitate indicated the presence of alkaloids.

\subsubsection{Phenols}

Two milliliters of $5 \%$ solution of $\mathrm{FeCl}_{3}$ were added to $1 \mathrm{ml}$ crude extracts. A black or blue-green colour indicated the presence of phenols.

\subsubsection{Tannins}

Two milliliters of $5 \%$ solution of $\mathrm{FeCl}_{3}$ were added 
to $1 \mathrm{ml}$ crude extracts. A black or blue-green colour indicated the presence of tannins.

\subsubsection{Flavonoid}

Three milliliters of crude extract was treated with $1 \mathrm{ml}$ of $10 \% \mathrm{NaOH}$ solution. The formation of an intense yellow colour was an indication of the presence of flavonoids.

\subsubsection{Saponins}

About $3 \mathrm{ml}$ of crude extracts were added to $3 \mathrm{ml}$ of distilled water and shaken vigorously. The formation of a stable persistent froth was taken as a positive test for saponins.

\subsubsection{Steroids}

Five milliliters of chloroform and $5 \mathrm{ml}$ of $\mathrm{H}_{2} \mathrm{O}_{4}$ were added to $500 \mu \mathrm{l}$ of the prepared crude extracts. The presence of steroids was indicated by a colour change from violet to blue or green or a ring of blue/green or if the upper layer turns red and the sulphuric layer was yellow with a green fluorescence.

\subsubsection{Terpenoids}

Approximately $2 \mathrm{ml}$ of chloroform and $3 \mathrm{ml}$ of $\mathrm{H}_{2} \mathrm{O}_{4}$ were added to $5 \mathrm{ml}$ of crude extracts. A reddishbrown coloration was taken as positive test for terpenoids.

The chemical component analysis was carried out on five extracts with a comparison of different ethanol concentrations.

The quantitative analysis used LCMS/MS instruments. In Analyzing mass spectrometers in LC-MS using Shimadzu LC-IT-TOF equipped with ESI. The ESI parameter has a voltage of $4.5 \mathrm{kV}$, with $200{ }^{\circ} \mathrm{C}$ capillary temperature, gas nebulizer $1.5 \mathrm{l} /$ minute. Operation of a mass spectrometer uses positive ion scanning modes from $200-2000 \mathrm{~m} / \mathrm{z}$. Utilize the Atrantis T3 water column $(2.1-150 \mathrm{~mm})$ and tem- perature starting at $40{ }^{\circ} \mathrm{C}$. Binary effluent of (A) 5 $\mathrm{mM}\left(\mathrm{NH}_{4}\right)$ OAc and (B) $\mathrm{CH}_{3} \mathrm{CN}$ solutions in the following gradient conditions: 0-30 minutes linear gradient from $10 \%-100 \% \mathrm{~B}, 30-40$ isocratic minutes at $100 \% \mathrm{~B}$ is the mobile phase. The flow rate is 0.2 $\mathrm{ml} /$ minute. The mass spectrometer in MS / MS analysis is in the range of $100-1000 \mathrm{~m} / \mathrm{z}$ to survey ions and the number of ions entered in the scan to MS / MS analysis automatically until results are obtained. The readable results on the computer are then processed with the MassLynx software and adjusted to the available literature.

\section{RESULTS and DISCUSSION}

\subsection{Extract yield}

The extract yields of the E100, E75, E50, E25, and A100 from the extraction of S. ligustrina wood were varying, which were $3.62-5.30 \%$. The statistical analysis showed that the solvent type affected the yield. Duncan's further test showed that the yield of the E50 was not significantly different from E75, but both were significantly different and higher than other extracts (Table 1). Just like the yield of licorice extract with ethanol solvent, the extract with ethanol concentration was $50 \%$ higher than the other concentrations (Ham and Kim, 2019). Solvents with different polarity affect the yield because different solvents dissolve different compounds according to their polarity and availability in extracted materials (Salamah et al., 2008).

The obtained of the E100 extract of S. ligustrina wood from this study (Table 1) was higher than the E100 obtained by Syafii (2016a), which was $4.11 \%$. It is due to the application of different extraction techniques. Syafii (2016a) used the ethanol extract obtained from extraction using multilevel polarity solvents (after extraction with n-hexane and acetyl acetate respectively). Hence the non-polar and semi- 
Table 1. The yield of S. ligustrina wood extracted by maceration method

\begin{tabular}{cc}
\hline Type of extract & Yield $(\%)^{*^{\mathrm{a}}}$ \\
\hline \hline E100 & $4.32 \pm 0.07 \mathrm{~b}$ \\
E75 & $5.19 \pm 0.11 \mathrm{~d}$ \\
E50 & $5.30 \pm 0.04 \mathrm{~d}$ \\
E25 & $4.70 \pm 0.41 \mathrm{c}$ \\
A100 & $3.62 \pm 0.15 \mathrm{a}$ \\
\hline
\end{tabular}

* average of 3 replications,

a The numbers in the same column followed by the same letters are not significantly different from the Duncan test.

polar extractive substances which can soluble in ethanol are extracted first into the n-hexane and ethyl acetate solvents which are used previously (Houghton and Raman, 1998). In this study, the ethanol extract was obtained from direct extraction using only ethanol solvents. The ethanol solvent is a universal solvent which can attract compounds which are soluble in non-polar and polar solvents and it have an polarity index of 5.2 (Snyder, 1997).

\subsection{Antimalarial activity}

The in vitro antimalarial activity of S. ligustrina wood extract showed that all extracts could inhibit $P$. falciparum parasite growth with varying inhibition percentages. Fig. 1 shows for each types of extract, an increase in the extract concentration has increased the inhibition percentage of $P$. falciparum parasites. However, the different types of extracts (based on differences in solvent) at the same of extract concentration caused differences in the inhibition percentage of these parasites. This difference is caused by the type and composition of different extractive substances (Syafii et al., 2016a).

The interpolation of the relationship between the concentration of extract and the inhibition percentage of parasites $P$. falciparum resulted in a regression equation. Based on the regression equation, $\mathrm{IC}_{50}$ value

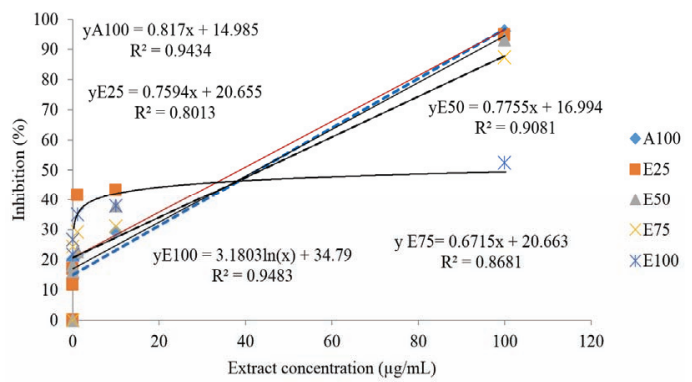

Fig. 1. The relationship Graph of the concentrations of the A100, E25, E50, E75, and E100 extracts of $S$. ligustrina wood with percent of the $P$. falciparum parasite inhibitors and regression equation.

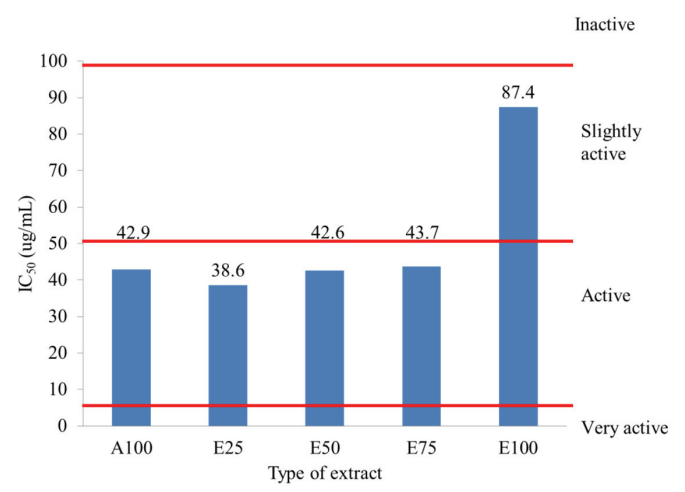

Fig. 2. The $\mathrm{IC}_{50}$ value of the A100, E25, E50, E75, and E100 extracts of S. ligustrina wood.

were obtained between 38.6-87.4 $\mu \mathrm{g} / \mathrm{mL}$ (Fig. 2). Based on the classification of antimalarial activity which refers to Chinchilla et al., (2011), the A100, E25, E50, and E75 extracts of S. ligustrina wood were classified as active because the $\mathrm{IC}_{50}$ values were $5-50 \mu \mathrm{g} / \mathrm{mL}$. The high antimalarial bioactivity of the ethanol extract is caused bythe presence of active compounds from groups of alkaloid compounds, flavonoids, triterpenoids, tannins and hydroquinones found in S. ligustrina wood (Syafii et al., 2016a). Ethanol is able to dissolve alkaloids, flavonoids, tannins (Harborne, 1987, Houghton and Raman, 1998), and hydroquinone (Depkes, 1995). Just like extract Cryptomeria japonicaleaves with acetone and water soluble fractions of methanol extract 
and ethanol fraction of hot water extract contained a lot of phenolic compounds and hydroxyl group, indicating that many hydroxyl groups and glycosidic bonds showed higher antioxidant effect than the other fractions (essential oil) (Kim et al., 2017). The hot water extracts of Ouercus mongolica and Rosa rugosa have potential antioxidant effects (Jung et al., 2017, Kim et al., 2018).

In Syafii's study (2016a), the E100 extract which was classified as very active ( $\mathrm{IC}_{50} 3.09 \mu \mathrm{g} / \mathrm{mL}$ ). It had higher antimalarial activity compared to this study because its $\mathrm{IC}_{50}$ value was lower (Fig. 2). It might be due to the fact that E100 from Syafii's research (2016a) was extracted with multilevel extraction using n-hexane and ethyl acetate hence nonpolar and semi-polar compounds have been extracted first in n-hexane and ethyl acetate. It was confirmed by n-hexane and ethyl acetate extract which were classified as an inactive antimalarial. But in this study, the antimalarial activity of E100 extract was classified as slightly active (Fig. 2). It may occur because ethanol was able to dissolve non-polar and semi-polar chemical compounds contained in S.ligustrina wood which resulted in slightly active antimalarial. Ethanol solvents can dissolve both semi-polar and non-polar extractives such as fats, waxes, and other compounds that do not have antimalarial activity (Syafii et al., 2016b).

\subsection{Phytochemical profile}

The qualitative phytochemical analysis showed that S. ligustrinawood extract was detected to contain groups of extractive substances in various intensities. It is because different types and polarity of solvents affect the type and composition of extracted phytochemical compounds. In addition, the solvent type will also affect the extracted bioactive compounds (Tiwari et al., 2011). In Table 2, the A100 and E25 extracts that have antimalarial activities which are classified as active (Fig. 2) were detected to contain very strong and strong flavonoids (Table 2). According to Widyawaruyanti et al. (2011), the group of flavonoids, especially prenylated flavones and chalcones, are reported to have high antimalarial activity. According to Bilia et al. (2006), the flavonoid group has an action mechanism by inhibiting the nutrients transport and inhibiting the degradation and detoxification of hemoglobin in Plasmodium. The E50 and E75 extracts were also classified as having antimalarial activities were detected to contain low flavonoids. But it detected to contain strong and very strong alkaloid, respectively. The alkaloids like strychnine had strong antimalarial activity (Syafii et al., 2016b). However, there has been no report about brucine antimalarial activity. Succeeded in isolating brucine in Strychnos nuxvomica plant which has anti-immfamatory and analgesic activity (Yin et

Table 2. Results of qualitative phytochemical analysis of S. ligustrina wood extract

\begin{tabular}{|c|c|c|c|c|c|c|}
\hline \multirow{2}{*}{$\begin{array}{c}\text { Active } \\
\text { compounds }\end{array}$} & \multicolumn{6}{|c|}{ The intensity of detection in qualitative analysis } \\
\hline & E100 & E75 & $\mathrm{E} 50$ & E25 & A100 & Powder \\
\hline Alkaloids & +++ & ++++ & +++ & +++ & ++ & ++ \\
\hline Phenol & +++ & ++ & ++ & ++ & + & +++ \\
\hline \multicolumn{7}{|l|}{ Hydroquinon } \\
\hline Tannins & + & + & + & ++ & + & - \\
\hline Flavonoids & + & + & + & +++ & ++++ & ++ \\
\hline Saponins & + & - & - & ++ & + & ++++ \\
\hline Steroids & + & + & + & + & + & + \\
\hline Terpens & + & + & ++ & ++ & ++ & ++ \\
\hline
\end{tabular}

- : undetectable, +: weak, ++: medium, +++ : strong, ++++ : very strong 
al., 2003). But brucine is a compound with the third largest relative concentration from S.ligustrina fraction 4 (very active antimalarial $\mathrm{IC}_{50} 0.386 \mu \mathrm{g} / \mathrm{ml}$ ) (Syafii et al., 2016b).

All extracts were containing various concentration of alkaloid compounds. Alkaloids were identified from the amount of sediment obtained by the addition of dragendorff reagents. Larger sediment means higher alkaloid content. The E75 extract was detected to contain very strong alkaloids, while the E100, E50, and E25 extracts were strong and the A100 extract was moderate (Table 2). S. ligustrina wood contains four alkaloid compounds, namely colobrin N-oxide, strychnine Noxide, brucine, and brucine $\mathrm{N}$-oxide. The higher alkaloids content are found in the stem and root of the plant (Hadi and Bremner, 2001). The action mechanism of alkaloids as an antimalarial is through inhibition of haem parasitic detoxification in food vacuoles, especially potential as blood schizontoside and gametocide (Hadi and Bremner, 2001, Depkes, 2008, and Mustofa, 2009).

The phytochemical test conducted by Frederich et al. (1999) revealed that the wood of the genus Strychnos contain strong alkaloid compounds and have the potential to be antimalarial. Sadono's research (2011) of the methanol extract of S. ligustrina wood has four main components, one of which is Strycnine which is one of the antimalarial compounds. The detection of alkaloid and flavonoid compounds in the S. ligustrina wood extract in this study is in line with previous studies. Syafii (2016a) showed that the E100 extract was detected to be very strong in alkaloids and strongly contain flavonoids and phenol hydroquinone. Therefore, the examination of S. ligustrina wood is crucial.

The LCMS/MS chromatograms of the E75, E50, and E25 extracts hadsimilar patterns. The metabolite profiling using LCMS/MS produced three complex data matrices which include the value of the mass to charge ratio $(\mathrm{m} / \mathrm{z})$, retention time, and peak intensity. The five extracts were identified to contain furan compounds, phenolic, aldehydes, alkaloids, fatty acids, lignans, and quinones with varying relative concentrations (Table 3). Table 3 shows that the main compounds of the five types of extract was brucine with different relative

Table 3. The results of LCMS / MS analysis of S. ligustrina wood extract

\begin{tabular}{|c|c|c|c|c|c|c|c|c|c|}
\hline \multirow{2}{*}{$\begin{array}{l}\text { Group of } \\
\text { compounds }\end{array}$} & \multirow{2}{*}{ Compound } & \multirow{2}{*}{ Formula } & \multirow{2}{*}{$\begin{array}{c}\mathrm{m} / \mathrm{z} \\
(\mathrm{g} / \mathrm{mol})\end{array}$} & \multirow{2}{*}{$\begin{array}{c}\text { Retention } \\
\text { time } \\
\text { (minutes) }\end{array}$} & \multicolumn{5}{|c|}{ Relative concentration (\%) } \\
\hline & & & & & E100 & E75 & E50 & E25 & A100 \\
\hline \multirow[t]{3}{*}{ Aldehyde } & 5-hidroksimetilfurfural & $\mathrm{C}_{6} \mathrm{H}_{6} \mathrm{O}_{3}$ & 126.111 & 2.05 & - & 0.001 & 0.01 & 0.02 & 0.02 \\
\hline & Guaiacol & $\mathrm{C}_{7} \mathrm{H}_{8} \mathrm{O}_{2}$ & 124.139 & 2.05 & 0.12 & 0.04 & 0.54 & 0.02 & 3.54 \\
\hline & Vanillin & $\mathrm{C}_{8} \mathrm{H}_{8} \mathrm{O}_{3}$ & 152.149 & 1.47 & 0.01 & 0.001 & 0.01 & 0.01 & 4.68 \\
\hline \multirow[t]{2}{*}{ Alkaloids } & Strychnine & $\mathrm{C}_{21} \mathrm{H}_{22} \mathrm{~N}_{2} \mathrm{O}_{2}$ & 334.419 & 3.90 & 0.12 & 0.04 & 0.54 & 0.94 & 3.54 \\
\hline & Brucine & $\mathrm{C}_{23} \mathrm{H}_{26} \mathrm{~N}_{2} \mathrm{O}_{4}$ & 394.471 & 5.61 & 11.62 & 11.79 & 21.33 & 24.55 & 24.96 \\
\hline \multirow[t]{3}{*}{ Fatty acid } & Palmitic acid & $\mathrm{C}_{16} \mathrm{H}_{32} \mathrm{O}_{2}$ & 256.43 & 4.77 & 0.44 & 0.49 & 0.97 & 1.16 & 3.54 \\
\hline & 9,11-octadecadienoic & $\mathrm{C}_{18} \mathrm{H}_{32} \mathrm{O}_{2}$ & 280.452 & 2.05 & - & 0.01 & 0.01 & 0.02 & 0.02 \\
\hline & acid Phyllamyricin A & $\mathrm{C}_{22} \mathrm{H}_{18} \mathrm{O}_{7}$ & 394.380 & 4.77 & 0.44 & 0.49 & 0.97 & 1.16 & 4.68 \\
\hline Lignans & 2-metoksihidrokuinon & $\mathrm{C}_{7} \mathrm{H}_{8} \mathrm{O}_{3}$ & 140.138 & 0.39 & - & - & 0.001 & 0.01 & 0.001 \\
\hline \multirow[t]{2}{*}{ Quinones } & Antrasena & $\mathrm{C}_{14} \mathrm{H}_{10} ;\left(\mathrm{C}_{6} \mathrm{H}_{4} \mathrm{CH}\right)_{2}$ & 178.234 & 0.39 & - & - & 0.001 & 0.01 & 0.001 \\
\hline & $\begin{array}{l}\text { 9,10-bis(4-metoksifenil) } \\
\text { antrasena }\end{array}$ & $\mathrm{C}_{28} \mathrm{H}_{22} \mathrm{O}_{2}$ & 390.482 & 8.09 & 0.78 & 0.29 & 0.98 & 0.62 & 2.49 \\
\hline
\end{tabular}


concentrations. The E25 extract as the most active extract ( $\mathrm{IC}_{50}$ value $38.6 \mu \mathrm{g} / \mathrm{mL}$ ) contained brucine with a relative concentration of $24.55 \%$, while extract of the E100 extract as an extract with the lowest antimalarial activity ( $\mathrm{IC}_{50}$ value $87.4 \mu \mathrm{g} / \mathrm{mL}$ ) contained brucine with the lowest concentration of $11.62 \%$. Although none of the literature reviews has reported brusin as an antimalarial compound, Syafii (2016b) reported that fraction four as the most active antimalarial fraction in the ethanol extract of S. ligustrina wood contained brucine. Another compound that plays a role in antimalarial activity is strychnine. Strychnine is an alkaloid compound found in parts of S. ligustrina wood (Setiawan et al., 2014) and has antimalarial activity (Frederich et al., 1999). In this study, the E25 extract contained $0.94 \%$ of strychnine, while the E100 extracts contained the lowest, which was $0.12 \%$ (Table 3 ).

The A100 extract contained higher brucine and strychnine compared to the E25 extract (Table 3). However, the $\mathrm{IC}_{50}$ value of the A100 extract was slightly lower than the E25 extract (Fig. 2). The A100 extract had a lower $\mathrm{IC}_{50}$. It may be caused by the high concentration of non-antimalaria compounds such as palmitic acid; 9.11 octadecadienoic acid; Guaiacol; Phyllamyricin A; and 9, 10-bis (4-methoxyphenyl) anthracene. The literature review showed that these compounds have been no reports on antimalarial activity (Syafii et al., 2016b).

\section{CONCLUSION}

The yield of S. ligustrina wood with ethanol and aqueous solvents at various concentrations was varied. The highest yield was obtained in the E50 extract (5.30\%), followed by E75 (5.19\%), E25 (4.70\%), E100 (4.32\%), and A100 (3.62\%). The S. ligustrina wood extracts of E25, E50, A100, and E75 had an active antimalarial activity with $\mathrm{IC}_{50}$ value of $38.6 \mu \mathrm{g} / \mathrm{mL}$, $42.6 \mu \mathrm{g} / \mathrm{mL}, 42.9 \mu \mathrm{g} / \mathrm{mL}$, and $43.7 \mu \mathrm{g} / \mathrm{mL}$, respectively.
However, the E100 extract was classified as slightly active with $\mathrm{IC}_{50}$ value of $87.4 \mu \mathrm{g} / \mathrm{mL}$. The qualitative phytochemical analysis showed that all extracts detected to contain strong alkaloids and phenolic compounds. The LCMS/MS analysis showed that the main compounds of all extracts were brucine and strychnine.

\section{ACKNOWLEDGMENT}

The authors thank the Directorate of Higher Education, Ministry of Education and Culture, Republic of Indonesia under 'Higher Education Research Grant of IPB' schemes for year 2018 (contract no. 1715/IT3. 11/PN/ 2018) for financial support.

\section{REFERENCES}

Bilia, A., Malgalhaes, R.P.M., Berganzi, M.C., Vincieri, F.F. 2006. Simultaneous analysis of artemisinin and obtained from a commercial sample and selected cultivar. Journal Phytomedicine 13: 487-493.

[BPOM] The Indonesian Food and Drug Administration. 2004. Fundamentals of food supplements. Jakarta, Indonesia.

Chinchilla, M., Valerio, I., Sanchez, R., Mora, V., Bagnarello, V., Martinez, L., Gonzalez, A., Vanegas, J.C., Apestegui, A. 2011. In vitro antimalarial activity of extracts of some plants from a biological reserve in Costa Rica. International Journal of Tropical Biology 60(2): 881-891.

[DEPHUT] Forestry Department. 2010. Multipart synergy in the cultivation, preservation and enhanced quality of Indonesian medicinal plants. Jakarta, Indonesia.

[DEPKES] The Indonesian Department of Health. 2008. Guidelines regulation malarial cases in Indonesia. Jakarta, Indonesia.

[DEPKES] The Indonesian Department of Health. 1995. Activities and management of mosquito hive eradication movement of Dengue fever. Jakarta, 
Antimalarial Activity and Phytochemical Profile of Ethanolic and Aqueous Extracts of Bidara Laut (Strychnos ligustrina Blum) Wood

Indonesia.

[DEPKES] The Indonesian Department of Health. 2012. Guidelines regulation malarial cases in Indonesia. Jakarta, Indonesia.

Frederich, M., Hayette, M.P., Tits, M., Mol, P.D., Angenot, L. 1999. In vitro of strychnos alkaloids and extracts against Plasmodium falciparum. Antimicrobe. Agents Chemother 43(9): 2328-2331.

Hadi, S., Bremner, B. 2001. Initial studies on alkaloids from Lombok medicinal plants. Molecules 6(2): 117-129.

Ham, Y., Kim, T.J. 2019. Conditions for preparing Glycyrrhiza uralensis extract for inhibiting biofilm formation of Streptococcus mutans. Journal of the Korean Wood Science and Technology 47(2): 178-188.

Harborne, J.B. 1996. The phytochemical method tokens the modern way of analyzing plants. Translated by Kosasih Padmawinata dan Imam Sudiro. Edition II. Bandung, Indonesia.

Houghton, P.J., Raman, A. 1998. Laboratory handbook for the fractionation of natural extracts. London (UK): Chapman \& hall.

Huda, C. 2006. Antimalarial activity water extract bidara sea (Strychnos ligustrina BI) wood against Plasmodium bergei in vivo, Skripsi, Airlangga University, Surabaya, Indonesia.

Jung, J.Y., Yang, J.K., Lee, W.H. 2017. Antioxidant and safety test of natural extract of Quercus mongolica. Journal of the Korean Wood Science and Technology 45(1): 116-125.

[KEMENKES] The Indonesian Ministry of Health. 2017. Indonesia territory malarial free dominant. Jakarta, Indonesia.

Kim, J.W., Um, M., Lee, J.W. 2018. Antioxidant activities of hot water extracts from different parts of Rugosa rose (Rosa rugosa Thunb.). Journal of the Korean Wood Science and Technology 46(1): 38-47.
Kim, S.H., Lee, S.Y., Cho, S.M., Hong, C.Y., Park, S.Y., Park, M.J., Choi, I.G. 2017. Antioxidant activities of Cryptomeria japonica leaves extracts by extraction methods. Journal of the Korean Wood Science and Technology 45(5): 495-510.

Kusch, P., Deininger, S., Specht, S., Maniako, R., Haubrich, S., Pommerening, T., Lin, P.K., Hoerauf, A., Kaiser, A. 2011. In vitro and in vivo antimalarial activity assays of seeds from Balanites aegyptiaca: Compounds of the extract show growth inhibition and activity against Plasmodial Aminopeptidase. Journal of Parasitology Research (2011): 1-9.

Mustofa. 2009. New antimalarial drugs: Between hope and reality (inauguration speech professorships). Gadjah Mada University. Yogyakarta, Indonesia. Sadono, A. 2011. Antioxidants and analysis of the components of the fenolik compound of the $S$. ligustrina, Thesis, Bogor Indonesia.

Salamah, E., Ayuningrat, E., Purwaningsih, S. 2008. Initial dispersion of the bioaktif component of kijing Taiwan (Anadonta woodiana Lea.) as an antioxidants compound. Bul Technol Fish. 11(2): 119-132.

Setiawan, O., Wahyuni, N., Susila, W.W., Rahayu, A. A.D., Rostiwati, T. 2014. S. ligustrina (S. ligustrina Blume) syn. S. lucida Br: Potential pharmaceutical resources in West Nusa Tenggara and Bali. Bogor, Indonesia.

Snyder, L.R., Joseph, J.K., and Joseph, L.G. 1997. Practical HPLC Method Development. Second Edition. New York (US): John Wiley and Sons, Lnc., pp. 722-723.

Syafii, W., Sari, R.K., Cahyaningsih, U., Anisa, L.N.2016a. Antimalarial activity of bidara sea ( $S$. ligustrina Blume). Journal of Tropical Wood Science Technology 14(1): 1-10.

Syafii, W., Sari, R.K., Cahyaningsih, U., Anisa, L.N. 2016b. Antimalarial activity of the fractions from ethanol extract of S. ligustrina Blume wood. Re- 
search Journal of Medicinal Plant 10(6): 403-408.

Tiwari, P., Kumar, B., Kaur, M., Kaur, G., Kaur, H. 2011. Phytochemical screening and extraction: a review. Int Pharma Science 1: 98-106.

Trager, W., Jensen, J.B. 1976. Human malaria parasites in continuous culture. Science 193(1): 673-675.

Widyawaruyati, A., Zaini, N.C., Syafruddin. 2011.

Antimalarial mechanisms and activity of a flavo- noid compound isolated from Cempedak (Artocarpus champeden Spreng Stembark). JBP 13(2): 67-77. Yin, W., Wang, T.S., Yin, F.Z., Cai, B.C. 2003. Analgesic and anti-inflammatory properties of brucine and brucine $\mathrm{N}$-oxide extracted from seeds of Strychnos nux-vomica. Journal of Ethnopharmacology 88: 205-214. 